Tropical Journal of Pharmaceutical Research July 2019; 18 (7): 1493-1497

ISSN: 1596-5996 (print); 1596-9827 (electronic)

(1) Pharmacotherapy Group, Faculty of Pharmacy, University of Benin, Benin City, 300001 Nigeria.

\title{
Polygonatum sibiricum extract exerts inhibitory effect on diabetes in a rat model
}

\author{
Lai-zeng $\mathrm{Yu}^{1}$, Xue-peng Zhang ${ }^{1}$, Ying-xin Wang ${ }^{2 \star}$ \\ ${ }^{1}$ Zhong Lu Hospital of Shandong University of Traditional Chinese Medicine, ${ }^{2}$ Shandong University of Chinese Medicine, Jinan, \\ Shandong Province 250355, China
}

*For correspondence: Email: wangyingxin494@126.com; Tel: +86 053189628015

Sent for review: 17 September 2018

Revised accepted: 17 June 2019

\begin{abstract}
Purpose: To investigate the effect of Polygonatum sibiricum extract (PSE) on streptozotocin-induced diabetic rats.

Methods: PSE was obtained by steeping the dried Polygonatum sibiricum in water at $60^{\circ} \mathrm{C}$ three times, each for $1 \mathrm{~h}$, before first drying in an oven at $100^{\circ} \mathrm{C}$ and then freeze-drying the final extract, thus obtained. Diabetic model rats were prepared by a single intraperitoneal injection of a freshly prepared solution of streptozotocin $(50 \mathrm{mg} / \mathrm{kg}$ ). The rats were randomly divided into 6 groups of ten rats each: negative control, normal control, reference (glibenclamide1 $\mathrm{mg} / \mathrm{kg}$ ) as well as PSE groups, (35, 70 and $140 \mathrm{mg} / \mathrm{kg}$ ). Blood glucose and plasma insulin levels were measured to determine antihyperglycemic effect. Oxidative stress was evaluated in liver and kidney by their antioxidant markers, viz, lipid peroxidation (LPO), superoxide dismutase (SOD), reduced glutathione (GSH), glutathione peroxidase $(G P x)$ and catalase $(C A T)$. Blood serum levels of creatinine and urea were determined in both diabetic control and treated rats.

Results: Compared with diabetic rats, oral administration of PSE at a concentration of $120 \mathrm{mg} / \mathrm{kg}$ daily for 30 days showed a significant decrease in fasting blood glucose $(118.34 \pm 3.29 \mathrm{mg} / \mathrm{dL})(p<0.05)$ and increased insulin level $(12.86 \pm 0.62 \mathrm{uU} / \mathrm{mL}, p<0.05)$. Furthermore, it significantly reduced biochemical parameters (serum creatinine, $0.83 \pm 0.21 \mathrm{mg} / \mathrm{dL}, p<0.05)$ and serum urea $(43.26 \pm 1.42 \mathrm{mg} / \mathrm{dL}, p<$ 0.05).

Conclusion: The results suggest that PSE may effectively normalize impaired antioxidant status in streptozotocin-induced diabetes in a dose-dependent manner. Thus, PSE has a protective effect against lipid peroxidation by scavenging free radicals, restoration of insulin function, and reduction of the incidence of complications.
\end{abstract}

Keywords: Polygonatum sibiricum, Diabetic, Antihyperglycemic, Antioxidant Oxidative stress, Fasting blood glucose

\begin{abstract}
This is an Open Access article that uses a fund-ing model which does not charge readers or their institutions for access and distributed under the terms of the Creative Commons Attribution License (http://creativecommons.org/licenses/by/4.0) and the Budapest Open Access Initiative (http://www.budapestopenaccessinitiative.org/read), which permit unrestricted use, distribution, and reproduction in any medium, provided the original work is properly credited.

Tropical Journal of Pharmaceutical Research is indexed by Science Citation Index (SciSearch), Scopus, International Pharmaceutical Abstract, Chemical Abstracts, Embase, Index Copernicus, EBSCO, African Index Medicus, JournalSeek, Journal Citation Reports/Science Edition, Directory of Open Access Journals (DOAJ), African Journal Online, Bioline International, Open-J-Gate and Pharmacy Abstracts
\end{abstract}

\section{INTRODUCTION}

Diabetes mellitus is a metabolic disease that manifests due to insulin insufficiency and/or insulin resistance and has become a serious health problem worldwide. In 2010, approximately 285 million adults between 20 and 79 years of age in the world were affected by 
diabetes and it is expected that 439 million adults will have diabetes by 2030 . The primary goals for the management of diabetes include the tight regulation of glucose levels in the blood and the prevention of diabetic complications [1]. Hyperglycemic control is crucial for the prevention and delay of the progression of diabetic complications.

Though diabetes is a non-communicable disease, it is considered to be one of the five leading causes of death in the world [2]. The disease is a complex metabolic disorder of the endocrine system. It is characterized by high blood glucose levels (hyperglycemia) due to the inability of the body cells to utilize glucose properly [3]. The increased blood glucose levels in diabetes produce superoxide anions, which generate hydroxyl radicals via Haber-Weiss reaction, resulting in peroxidation of membrane lipids and protein glycation. This leads to oxidative damage of cell membranes. These radicals further damage other important biomolecules including carbohydrates, proteins and deoxyribonucleic acid (DNA) [4-7].

Medicinal plants are widely used by the people of developing countries as alternative therapy. In China, hundreds of plants are used traditionally for the management of diabetes. Unfortunately, only a few of such Chinese medicinal plants have received scientific scrutiny. Despite the long traditional use of Polygonatum sibiricum in diabetes [8,9], no systematic pharmacological work has been carried out on this plant. The present study was therefore designed to study the hypoglycemic effect of Polygonatum sibiricum extract against streptozotocin induced diabetic rats.

\section{EXPERIMENTAL}

\section{Plant material and extraction}

Samples of Polygonatum sibiricum were collected from Dali City, Yunan Province in China in October 2017. Taxonomic identification of the plant was performed by Professor Ling $\mathrm{Hu}$ of Shandong University of Chinese medicine in China. A voucher specimen (no. PSE 20171005) was deposited in the herbarium of College of Pharmacy, Shandong University of Chinese Medicine, China for future reference.

The whole plant of Polygonatum sibiricum was dried in a drying oven at $100{ }^{\circ} \mathrm{C}$ for $12 \mathrm{~h}$. PSE was obtained by steeping the dried Polygonatum sibiricum in water at $60{ }^{\circ} \mathrm{C}$ for three times. The performance was repeated for $1 \mathrm{~h}$ each. Then the last extract was obtained after being dried in an oven. One gram powder was obtained from about $1.8 \mathrm{~g}$ dried sample, i.e., a yield of $55.6 \%$.

\section{Animals}

SPF male Wistar rats, weighing 200 - $220 \mathrm{~g}$, were provided by the Experimental Animal Center of Shandong Province (certificate no. SYXK2005 - 0002). The animals had free access to food and water, and were allowed to acclimatize for at least one week before use. The rat experiment was approved by the Animal Care and Use Committee of Shandong University of Chinese medicine (approval ref no. 20060807) and was carried out in compliance with Directive $2010 / 63 / E U$ on the handling of animals used for scientific purposes [10].

\section{Animal groups}

The rats were randomly divided into 6 groups of ten rats each: negative control group, model group, reference group (glibenclamide $1 \mathrm{mg} / \mathrm{kg}$ ) as well as PSE groups, namely, 35, 70 and 140 $\mathrm{mg} / \mathrm{kg}$. Treatments (in aqueous solution) were given orally once daily for 30 days.

\section{Preparation of experimental diabetes}

The animals were fasted overnight and diabetes was induced by a single intraperitoneal injection of a freshly prepared solution of streptozotocin $(50 \mathrm{mg} / \mathrm{kg})$ in citrate buffer $(\mathrm{pH} \mathrm{4.5)}[11,12]$. After three days of STZ-injection, the rats were fasted for $6 \mathrm{~h}$ and blood was withdrawn by retroorbital puncture under ether anesthesia. Rats with moderate diabetes having hyperglycemia (that is, with blood glucose of $250-400 \mathrm{mg} / \mathrm{dL}$ ) were used for the experiment [13].

\section{Biochemical analysis}

Rats were fasted overnight and the blood was withdrawn by retro orbital puncture under light ether anesthesia on the $1^{\text {st }}, 15^{\text {nd }}$ and $30^{\text {th }}$ day post induction to determine blood glucose and plasma insulin level. The change in body weight was observed throughout treatment period in the experimental animals. At the end of 30 days, the animals were sacrificed by cervical decapitation for serum biochemical parameters examination (hemoglobin, glycosylated $\mathrm{Hb}$, total protein, serum creatinine, serum urea). Blood was collected from the heart in two different tubes, i.e. one with anticoagulant for plasma, and another with anticoagulant for serum separation. Serum was separated by centrifugation $3500 \mathrm{rpm}$ at 25 ${ }^{\circ} \mathrm{C}$ for 10 min. Fasting blood glucose was estimated by O-toluidine method [14]. Plasma insulin level was assayed by the radio- 
immunoassay method. All biochemical tests were carried out in our lab by using commercial kits obtained from Erba diagnostic Mannheim Gmbh, Germany.

\section{Oral glucose tolerance test}

The rats were divided into four groups of 10 animals each. Group I served as control and received distilled water. Group II served as diabetic control and received distilled water. Group III served as positive control, received glibenclamide (1 mg/kg). Group IV received PSE $70 \mathrm{~g} / \mathrm{kg}$ orally. The rats were fasted for $18 \mathrm{~h}$ and the test was performed by oral administration of glucose $(2 \mathrm{~g} / \mathrm{kg})$ to diabetic and normal rats 30 min after dosing. Blood samples were collected from the retro-orbital (under light ether anesthesia) immediately (0), 30, 60, 90, and 120 min after the glucose administration and the blood glucose levels were estimated.

\section{Statistical analysis}

Data are presented as mean \pm standard deviation (SD), and were analyzed by one-way ANOVA followed by Tukey's multiple comparison using SPSS 17.0 software for Windows. Differences were considered statistically significant at $p<0.05$.

\section{RESULTS}

\section{Effect of PSE on blood glucose and plasma insulin}

Fasting blood glucose levels in the negative group of rats remained unchanged during the course of the experiment. Compared to normal group, level of fasting blood glucose was significantly $(p<0.01)$ higher and the plasma insulin level was significantly decreased in diabetic groups. On the other hand, administration of PSE for 30 days was found to lower the blood glucose and increase the insulin level significantly $(p<0.01)$ in a dose dependent manner when compared with control groups (Table 1 and Table 2).

\section{Effect of PSE on biochemical parameters}

STZ induced significant $(p<0.05)$ elevations in serum creatinine and urea levels and decrease in total protein when compared to normal group. However, treatment with different doses of PSE significantly $(p<0.05)$ reduced serum creatinine and serum urea level and increased total protein when compared to those of diabetic control groups (Table 3).

Table 1: Effect of PSE on blood glucose level in rats (mean $\pm S D, n=10$ )

\begin{tabular}{lcccc}
\hline Group & Dose $(\mathbf{m g} / \mathbf{k g})$ & \multicolumn{3}{c}{ Blood glucose $(\mathbf{g} / \mathbf{d L})$} \\
\cline { 3 - 5 } & & Initial & Day 15 & Day $\mathbf{3 0}$ \\
\hline Negative & - & $52.56 \pm 2.14$ & $88.37 \pm 2.86^{* *}$ & $68.24 \pm 2.64^{* *}$ \\
Model & - & $283.14 \pm 2.06$ & $329.34 \pm 3.25$ & $331.09 \pm 3.78$ \\
GLI & 1 & $279.35 \pm 2.12$ & $159.16 \pm 3.08^{* *}$ & $125.27 \pm 2.64^{* *}$ \\
PSE-L & 35 & $271.25 \pm 3.07$ & $262.34 \pm 3.24^{*}$ & $234.15 \pm 3.47^{*}$ \\
PSE-M & 70 & $285.24 \pm 2.28$ & $234.22 \pm 3.86^{* *}$ & $164.08 \pm 3.15^{* *}$ \\
PSE-H & 140 & $263.54 \pm 2.17$ & $235.38 \pm 3.18^{* *}$ & $118.34 \pm 3.29^{* *}$
\end{tabular}

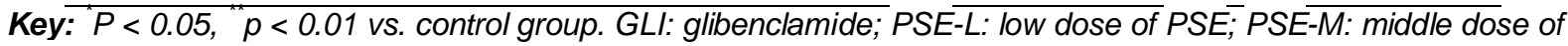
PSE; PSE-H: high dose of PSE

Table 2: Effect of PSE on plasma insulin level in rats (mean $\pm S D, n=10$ )

\begin{tabular}{lcccc}
\hline Group & Dose $(\mathbf{m g} / \mathbf{k g})$ & \multicolumn{3}{c}{ Plasma insulin (uU/mL) } \\
\cline { 3 - 5 } & & Initial & Day15 & Day 30 \\
\hline Negative & - & $28.15 \pm 0.69$ & $19.25 \pm 0.74^{* *}$ & $16.57 \pm 0.43^{* *}$ \\
Model & - & $6.47 \pm 0.35$ & $5.16 \pm 0.47$ & $3.25 \pm 0.38$ \\
GLI & 1 & $5.18 \pm 0.42$ & $15.27 \pm 0.54^{* *}$ & $14.42 \pm 0.52^{* *}$ \\
PSE-L & 35 & $6.33 \pm 0.25$ & $7.33 \pm 0.72^{*}$ & $9.15 \pm 0.66^{*}$ \\
PSE-M & 70 & $5.73 \pm 0.51$ & $12.18 \pm 0.62^{* *}$ & $11.26 \pm 0.74^{* *}$ \\
PSE-H & 140 & $6.34 \pm 0.39$ & $10.39 \pm 0.71^{* *}$ & $12.86 \pm 0.62^{* *}$
\end{tabular}

Key: $P<0.05, " p<0.01$ vs. control group. GLI: glibenclamide; $P S E-L$ : Iow dose of PSE; PSE-M: middle dose of PSE; PSE-H: high dose of PSE 
Table 3: Effect of PSE on biochemical parameters in rats (mean $\pm S D, n=10$ )

\begin{tabular}{|c|c|c|c|c|c|c|}
\hline Group & $\begin{array}{c}\text { Dose } \\
(\mathrm{mg} / \mathrm{kg})\end{array}$ & $\begin{array}{l}\text { Hemoglobin } \\
\text { (mg/dL) }\end{array}$ & $\begin{array}{c}\text { Glycosylated } \mathrm{Hb} \\
(\mathrm{Hb} \%)\end{array}$ & $\begin{array}{l}\text { Serum } \\
\text { creatinine } \\
(\mathrm{mg} / \mathrm{dL})\end{array}$ & $\begin{array}{l}\text { Serum urea } \\
\text { (mg/dL) }\end{array}$ & $\begin{array}{c}\text { Total } \\
\text { proteins } \\
(\mathrm{g} / \mathrm{dL})\end{array}$ \\
\hline Negative & - & $14.26 \pm 2.18$ & $6.64 \pm 0.72$ & $0.73 \pm 0.15$ & $28.41 \pm 1.53$ & $9.68 \pm 1.36$ \\
\hline Model & - & $9.13 \pm 1.43$ & $18.28 \pm 1.06$ & $2.85 \pm 0.21$ & $81.23 \pm 2.15$ & $3.34 \pm 1.15$ \\
\hline GLI & 1 & $11.43 \pm 2.28$ & $12.42 \pm 0.68$ & $0.93 \pm 0.20$ & $37.43 \pm 1.27$ & $7.28 \pm 1.41$ \\
\hline PSE-L & 35 & $9.86 \pm 1.41^{\circ}$ & $13.15 \pm 0.72$ & $1.73 \pm 0.14$ & $73.36 \pm 2.18^{\circ}$ & $6.39 \pm 1.04$ \\
\hline PSE-M & 70 & $10.29 \pm 1.34$ & $11.17 \pm 0.56$ & $1.34 \pm 0.15^{\star}$ & $55.19 \pm 1.84$ & $6.46 \pm 1.25$ \\
\hline PSE-H & 140 & $12.15 \pm 1.59^{\pi}$ & $9.18 \pm 0.48^{x}$ & $0.83 \pm 0.21$ & $43.26 \pm 1.42$ & $7.46 \pm 1.18$ \\
\hline
\end{tabular}

\section{DISCUSSION}

Diabetes is a metabolic disorder of carbohydrate, fat and protein, affecting a large number of population in the world [1]. Diabetes mellitus is not a single disorder but it is a group of metabolic disorder characterised by chronic hyperglycemia, resulting from defects in insulin secretion, insulin action, or both. Increased thirst, increased urinary output, ketonemia and ketonuria are the common symptoms of diabetes mellitus, which occur due to the abnormalities in carbohydrate, fat, and protein metabolism. Chinese medicinal herbs have been shown to exert hypoglycemic activities through stimulation of insulin release [15]. It is assumed that Polygonatum sibiricum extract could be responsible for stimulation of insulin and the restoration of metabolic activity.

Diabetic hyperglycemia induces elevation of serum level of urea and creatinine, which were considered as significant markers of renal dysfunction [16]. Increase in serum level of urea and creatinine levels in STZ-diabetic rats may indicate diminished ability of the kidney to filter these waste products from the blood and excrete them in the urine. The results indicate that treatment of diabetic group with Scrophularia ningpoensis extract significantly reduced serum urea and creatinine level. Based on these findings, PSE may enhance the ability of the kidney to remove these waste products from the blood in diabetic rats. Catalase has been shown to be responsible for the detoxification of $\mathrm{H}_{2} \mathrm{O}_{2}$, and protect the tissues from highly reactive hydroxyl radicals [19]. The decrease in CAT activity could have resulted from in activation by glycation of enzyme [20]. In the present study, extract-treated groups showed a significant increase in the hepatic and renal SOD and CAT activities of the diabetic rats. This means that the extracts can reduce the potential glycation of enzymes or they may reduce reactive oxygen free radicals and improve the activities of antioxidant enzymes. This result clearly shows that Polygonatum sibiricum contains free radical scavenging activity, which could exert a beneficial action against pathological alteration caused by the presence of superoxide radicals and hydrogen peroxide radical.

\section{CONCLUSION}

The pronounced antioxidant effect of PSE as well as its inhibitory activity against some relevant biochemical enzymes in rats suggest that it is a potential anti-diabetic therapy for humans.

\section{DECLARATIONS}

\section{Conflict of interest}

No conflict of interest is associated with this work.

\section{Contribution of authors}

We declare that this work was done by the authors named in this article and all liabilities pertaining to claims relating to the content of this article will be borne by the authors. Ying-xin Wang conceived and designed the study, Laizeng $Y u$ and Xue-peng Zhang collected and analysed the data.

\section{Open Access}

This is an Open Access article that uses a funding model which does not charge readers or their institutions for access and distributed under the terms of the Creative Commons Attribution License (http://creativecommons.org/licenses/by/ 4.0) and the Budapest Open Access Initiative (http://www.budapestopenaccessinitiative.org/rea d), which permit unrestricted use, distribution, and reproduction in any medium, provided the original work is properly credited.

\section{REFERENCES}

1. Shaw JE, Sicree RA, Zimmet PZ. Global estimates of the prevalence of diabetes for 2010 and 2030. Diabetes Res Clin Pract 2010; 87: 4-14. 
2. Rahati S, Shahraki M, Arjomand G, Shahraki T. Food pattern, lifestyle and diabetes mellitus. Int $J$ High Risk Behav Addict 2014; 3: e8725-8726.

3. Kurakane S, Yamada N, Sato H, Igarashi K. Anti-diabetic effects of Actinidia arguta polyphenols on rats and KKAy mice. Food Sci Technol Res 2011; 17: 93-102.

4. Baynes JW. Role of oxidative stress in development of complications in diabetes. Diabetes 1991; 40: 405-412.

5. Oberley LW. Free radicals and diabetes. Free Rad Biol Med 1988; 5: 113-124.

6. Jacob RA. The integrated antioxidant system. Nutrit Res 1995; 15: 755-767.

7. Baynes JW. Reactive oxygen in the etiology and complications of diabetes. In: loannides C, Flatt PR, Eds, Drug, Diet and Disease: Mechanistic Approach to Diabetes, vol. 2. Ellis Horwood Limited, Hertfordshire, 1995. 203-231.

8. Sha WJ, Lu H. The research progress of astragalus in regulating blood glucose steady state of diabetes patients. Int J Trad Chin Med 2015; 37: 87-89.

9. Gao Y, Guo J, Ren SP. Effect of Radix Astragali on blood glucose, TG, HDL-C, LDL-C and insulin levels in diabetic rats. Chin J Ger 2008; 28: 1676-1677.

10. European Commission [homepage on the internet]. Directive 2010/63/EU on the protection of animals used for scientific purposes [cited 2013 Jan 16]. Availablefrom:http://ec.europa.eu/environment/chemical s/lab_animals/legislation_en.htm.

11. Hemalatha S, Wahi AK, Singh PN, Chansouria JP. Hypoglycemic activity of Withania Coaculants Dunal in streptozotocin induced diabetic rats. J Ethnopharmacol 2004; 93: 261-264.
12. Balasubramaian $R$, Kasiappan $R$, Vengidusamy $N$, Muthusamy $K$, Sorimuthu $S$. Protective effect of macrocyclic binuclear oxovanadium complex on oxidative stress in pancreas of streptozotocin induced diabetic rats. Chem Biol Interact. 2004; 149: 9-21.

13. Burcelin R, Eddouks M, Maury J, Kande J, Assan R, Girard J. Excessive glucose production, rather than insulin resistance, account for hyperglycemia in recent onset streptozocin-diabetic rats. Diabetologia 1995; 35 : 283-290.

14. Sasaki T, Matzy S, Sonal A. Effect of acetic acid concentration on the colour reaction in the O-toluidine boric acid method for blood glucose estimation. Rinsh Kagaku 1972; 1: 346-353.

15. Prince PSM, Menon VP. Hypoglycemic and other related action of Tinospora cordifolia roots in alloxan rats. $J$ Ethnopharmacol 2000; 70: 19-25.

16. Almdal TP, Vilstrup $H$. Strict insulin treatment normalizes the organic nitrogen contents and the capacity of urea- $N$ synthesis in experimental diabetes in rats. Diabetologia 1988; 31: 114-118.

17. Carrascosa JM, Molero JC, Fermín Y, Martínez $C$, Andrés A, Satrústegui J. Effects of chronic treatment with acarbose on glucose and lipid metabolism in obese diabetic Wistar rats. Diabetes Obes Metab 2001; 3: 240248.

18. Fujita $H$, Yamagami $T$. Fermented soybean-derived Touchi-extract with anti-diabetic effect via alphaglucosidase inhibitory action in a long-term administration study with KKAy mice. Life Sci 2001; 70: 219-27. 